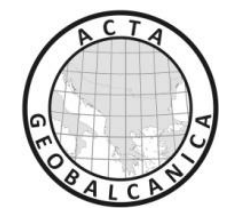

\title{
DIFFERENT APPROACHES TO THE URBAN-RURAL TYPOLOGY: DIFFERENT VIEWS ON DISTRIBUTION OF URBAN AND RURAL POPULATION IN SLOVAKIA
}

\author{
Vladimír Székely ${ }^{1}$ \\ ${ }^{1}$ Institute of Geography Slovak Academy of Sciences, Slovakia \\ Corresponding author: szekely@savba.sk
}

\begin{abstract}
The official governmental documents about rural development for individual programming periods had used different identification of rural areas. The aim of the article is to provide the concise presentation and comparison of various theoretical- methodological approaches to the definition and delimitation of urban and rural areas that were applied and are used by scientific and expert community in Slovakia during the processes of preparing these documents. We present the difficulties and critical statements about application of administrative and statistical NUTS III and LAU 1 spatial units for deeper understanding of rural problems in extremely spatially differentiated Slovakia.
\end{abstract}

Keywords: urban-rural typology, definition and delimitation of rural areas, distribution of population, Slovakia.

\section{INTRODUCTION}

Definition and delimitation of urban and rural spaces can be seen as a long-standing traditional problem of several spatial science disciplines (human and regional geography, spatial sociology, spatial economy, regional science, ...). For example, in rural geography it is generally accepted that the question of correct conceptual and spatial delimitation of rural areas has no clear, generally valid and broadly applicable answer because of the wide range of various opinions and theoretical, respectively pragmatic methodological approaches and constructions [8]. It not unusual that by the description of population and/or settlement structure of selected spatial units is in numerous geographic works used the number and share of rural, respectively urban population without deeper analysis, or eventually an explanation which methodology was used for obtaining numeric values. This fact becomes very problematic not only by the existence of multiple different values of rurality and/or urbanity, respectively different patterns of urban-rural typology for one concrete state (region), but also by numerous international comparisons with more or less surprising methodologies and results. The outcome is time- spatial incompatibility and individualistic interpretation of achieved results. Naturally such chaotic state full of ambiguity, docility and relativeness causes broad range of problems. 
The aim of this article is to provide the concise presentation of various theoreticalmethodological approaches to the definition and delimitation of urban and rural areas that were applied and are used by scientific and expert community in Slovakia during the processes of preparing the governmental documents about rural development.

\section{METHODOLOGY}

According to Hurbánek [6] there are three approaches used for defining rural areas: 1. Administrative (rural areas as a complement to areas that attained the statute of a town), 2. Conceptual (usage of spatial, structural characteristics - population density, settlements density, land cover and land use- as well as non-spatial, functional characteristics - demographic, social, cultural, economic and ecological features of examined areas) and 3. the approach derived from a certain policy (e.g. EU Common Agricultural Policy which has crucial influence on EU rural development policy and delimitation of rural areas in EU Member States).

While defining rural territories it is important to distinguish between rural municipalities and rural areas [8]. Approaches to delimitation of urban and rural municipalities that responded to changed conditions caused by the urbanization process are summarized in the study of Podolák [9]. He wrote: "In the past, historical criteria were used to define the town. Later, with ongoing urbanization, the quantitative features and the size of settlements were taken into account" (p.50). Delimitating of urban and rural municipalities became the matter of the Statistical Service, which also took into account the geographical criteria. Starting from 1961, every population census was accompanied by a separate classification discerning the municipalities (communes) of urban and rural type [1]. In the 1960s, the so-called status of town, approved by the Ministry of Interior was a new element applied to classification of towns. In the course of the following years, confession of the status of town became the decisive differentiating criterion for classification of a municipality as urban. According to the Act of the Slovak National Council No.369/1990 about municipal establishment, status of town can be obtained by the municipality, which fulfils the following conditions: 1 . it is an economic, administrative and cultural centre, or centre of tourism, or it is a spa, 2. it secures services for population living in the surrounding communes, 3 . it has transport communication with the surrounding municipalities, 4. at least part of its territory is covered by urban fabric, and 5 . its population is at least 5, 000. However, also a municipality that does not comply with the condition of population number can obtain the status of town, if it fulfils all above quoted legal requests.

Confession of the town status by the National Council of the Slovak Republic is now the decisive criterion for delimitation of urban municipalities. Starting from Census 1991, all other municipalities are rural. Tab.1 provides an overview of how the share of people living in in rural municipalities (municipality is a basic administrative unit that often consists of numerous spatially dispersed settlements) is increasing - the rural environment is becoming more and more attractive for permanent residence during the period 1991-2011. However, these numeric values can be in an instant changed without the population movement, simply by integration or disintegration of municipalities, and/or by changing the status of municipalities from rural to urban. 
Tab.1. Administrative urban-rural division of municipalities and population in Slovakia: the Censuses 1991, 2001, 2011.

\begin{tabular}{lcccccc}
\hline Municipalities & \multicolumn{2}{c}{1991} & \multicolumn{2}{c}{2001} & \multicolumn{2}{c}{2011} \\
\cline { 2 - 7 } & $\begin{array}{c}\text { Number of } \\
\text { municipalities }\end{array}$ & $\begin{array}{c}\text { Population } \\
\text { in \% }\end{array}$ & $\begin{array}{c}\text { Number of } \\
\text { municipalities }\end{array}$ & $\begin{array}{c}\text { Population } \\
\text { in \% }\end{array}$ & $\begin{array}{c}\text { Number of } \\
\text { municipalities }\end{array}$ & $\begin{array}{c}\text { Population } \\
\text { in \% }\end{array}$ \\
\hline Urban & 136 & 56.8 & 136 & 56.2 & 138 & 54.4 \\
\hline Rural & 2689 & 43.2 & 2747 & 43.8 & 2752 & 45.6 \\
\hline
\end{tabular}

Because of the fact that national definitions of rural and urban spaces in Europe (and in the world) significantly differ [8], one methodology was seeked in order to compare the urban-rural dichotomy in individual national states. Since 1994 the OECD methodology [7] has been used. Thanks to its simplicity it has been relatively frequently applied mostly by the preparation of governmental documents, e.g. such as the "Rural development plan". It was based primarily on delimiting basic administrative units municipalities (obec in Slovakia, the statistical unit LAU 2) that are classified as rural or not rural. As the key criterion was selected the density of population while the division line (threshold value) between rural and urban municipality was defined the value 150 inhabitants $/ \mathrm{km}^{2}$. Municipalities with the population density below 150 inhabitants $/ \mathrm{km}^{2}$ were considered rural. After applying this first level of the delimitation of rural municipalities, the second level was used - the classification of administrative and statistical units at the level of NUTS III (administrative region - kraj in Slovakia; in 1996 eight administrative regions and 79 districts (LAU 1) were formed as a consequence of the new territorial-administrative division in Slovakia), forming three categories of the urban-rural typology:

- Predominantly urban regions - with less than $15 \%$ of inhabitants living in rural municipalities,

- Significantly rural (Intermediate) regions - with 15 to $50 \%$ of inhabitants living in rural municipalities,

- Predominantly rural regions - more than $50 \%$ of inhabitants live in rural municipalities.

Spatial units that are used in urban-rural typology are predetermined. Being predominantly the products of political decision-making they are criticized from the side of geographers. For example as Bezák [2] expressed: "as far as the number of administrative regions and the choice of their administrative centers and demarcation of their boundaries are concerned, there exists a serious disproportion between the present regional structure and the new territorial-administrative division of Slovakia" (p.301). However, the experience of the last years shows that regional units linked to the territorial-administrative units (which represent also the statistical units NUTS III and LAU 1) clearly determine the regional analyses and the problem pointed to by Bezák is rather (in spite of its rationale) widely ignored not only in the official governmental documents (such as the "Rural development programme"), but also in basic research.

The categorization of administrative and statistical units NUTS III and LAU 1 - their degree of rurality - depends mainly from the applied criteria. In this article it is pointed out how can be the urban-rural category of a spatial unit changed by applying different threshold values while defining rural municipality and/or individual categories. Three 
governmental documents focusing on urban-rural typology are examined at the level of administrative regions (NUTS III), and two of them are examined at the level of districts (LAU 1) which reflects spatial differentiation of Slovakia better than traditional NUTS III units. While in the "Rural development plan 2004-2006 - Slovak Republic" was as a rural municipality considered the municipality with the population density lower than 100 inhabitants $/ \mathrm{km} 2$ (possibly only as an experiment), in the "National strategic plan for the rural development of the Slovak Republic for the programming period 2007-2013" the threshold value 150 inhabitants $/ \mathrm{km}^{2}$ was applied by defining rural municipality. It is a paradox, but we do not know the exact applied criteria for the new, revised urban-rural typology in Slovakia which is used in "Rural Development Programme in Slovakia for the 2014-2020 programming period" - we know only the division of administrative regions (NUTS III) into 3 categories [4].

\section{RESULTS}

Because the OECD methodology is considered as imperfectly reflecting the rural character of areas [6], it is important to take into consideration that the expectation of scientific correctness and exactness while interpreting results would be a speculation. There are a lot of reasons for such statement, but the urban-rural typology based on the utilizing the relatively large and internally inconsistent NUTS III units with the size and shape of the territory created on the basis of political consensus for the purpose of state administration, is one of the most relevant one. This is also the reason why hierarchically lower units, LAU 1 (districts), are used for regional analysis.

Regarding the "Rural development plan 2004-2006", the threshold value of density of population for rural/non-rural municipality was determined on 100 inhabitants $/ \mathrm{km}^{2}$. The municipalities with density of population below this value had been defined as "rural". At the regional level NUTS III only Bratislava region, where according to the data from 1999 lived around $11.4 \%$ of the total population of Slovakia, was considered as "predominantly urban" (fig.1). The next 7 regions (rest of Slovakia) had been officially declared as "rural regions" in spite of their category as "significantly rural (intermediate) regions". The declaration of Slovakia as a "rural country", where $88.6 \%$ of Slovak population lived in rural regions, was the consequence of the applied approach to urban-rural typology. The reason was that the "predominantly rural" regions, which were not represented at the level of NUTS III, and "significantly rural (or intermediate)" regions are usually jointly considered as "rural". However, if the "significantly rural (intermediate) regions" would be aggregated with the "predominately urban regions", the extreme situation would occur $-100 \%$ of the population of Slovakia would live in urban regions. Hence, it is obvious that the results of such a methodological approach and their following interpretation (in spite of potentially very limited knowledge of regional geography of Slovakia) are untrustworthy and therefore scientifically incorrect. 


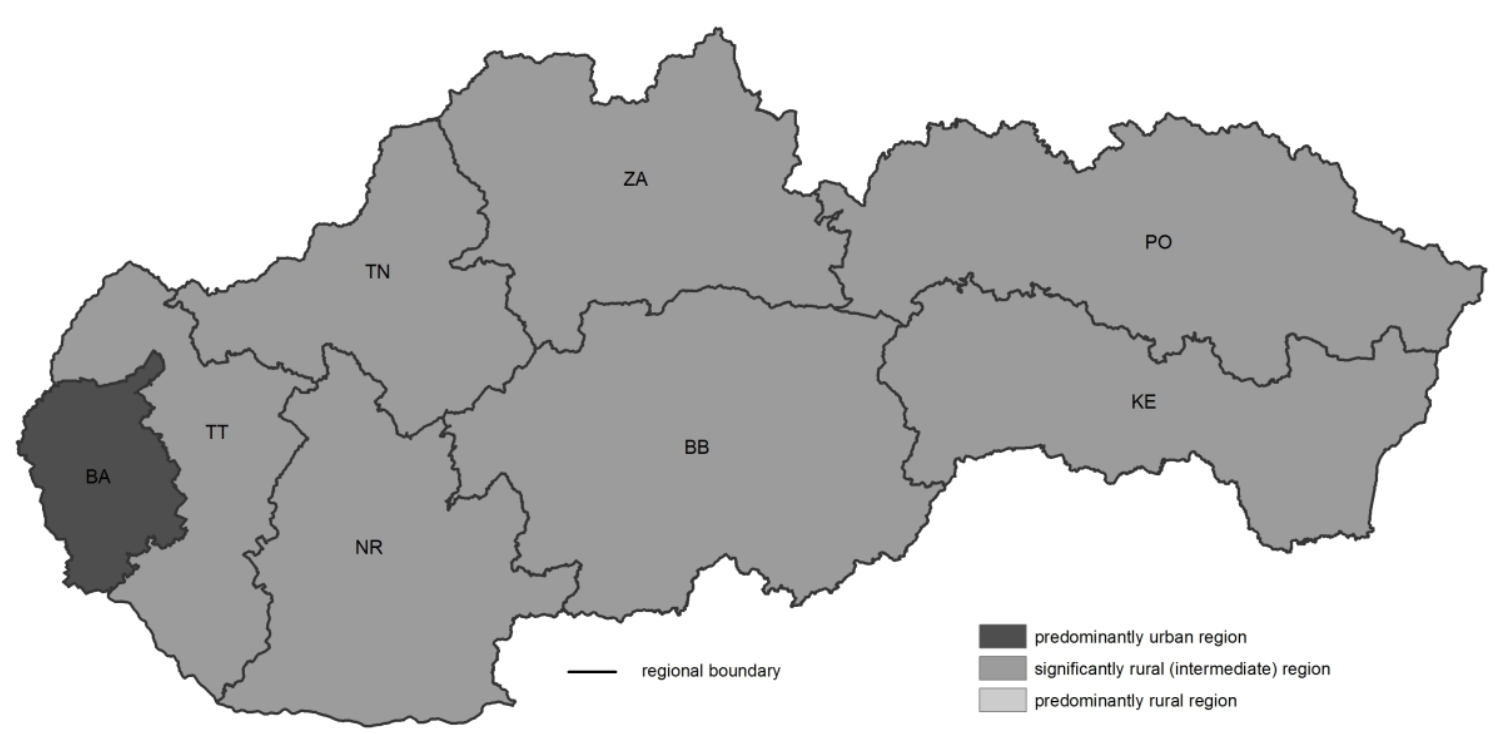

Fig.1. Urban-rural typology (for 2004-2006 period) on the NUTS III level (rural municipality = density of population is below 100 inhabitants $/ \mathrm{km}^{2}$ )

Administrative and statistical NUTS III regions of Slovakia: $\mathrm{BA}=$ Bratislava region, $\mathrm{TT}=$ Trnava region, $\mathrm{TN}=$ Trenčín region, $\mathrm{NR}=$ Nitra region, $\mathrm{ZA}=$ Žilina region, $\mathrm{BB}=$ Banská Bystrica region, $\mathrm{PO}=$ Prešov region, $\mathrm{KE}=$ Košice region

If the definition and characteristics of rurality of Slovakia is done at the level of administrative districts (LAU 1) by dividing homogenous NUTS III units into the mosaic of heterogeneous spatial units, different values for each category of the urbanrural typology is obtained at the national level. It needs to be emphasized that these values are more accurate, have higher explanatory power and better characterize Slovak reality. Indeed, the values are again influenced by the threshold value for defining rural municipality. Using the "Rural development plan 2004-2006" as an example, 11 "predominantly rural regions" existed at the level of LAU 1, inhabited by $10.1 \%$ of Slovak population. In 57 "intermediate (significantly rural) regions" lived $75.3 \%$ inhabitants of Slovakia and in 11 "predominantly urban region" represented primarily by 9 urban districts of 2 Slovak metropolitan settlements - Bratislava and Košice - lived $14.6 \%$ of Slovak population.

In the following programming period 2007-2013 was for the urban-rural typology selected the OECD methodology by which the rural municipality is defined as the municipality with the population density lower than 150 inhabitants/km2 [7]. In governmental document for the rural development in this programming period were at the level of NUTS III defined 2 administrative regions (Nitra, Banská Bystrica) as "predominantly rural" with $25.4 \%$ of Slovak population. Bratislava region was as the only one considered to be "predominantly urban region" with the $11.2 \%$ share of the total Slovak population. Remaining 5 administrative regions (Trnava, Trenčín, Žilina, Prešov, Košice) with $63.4 \%$ of the population belonged to the category "significantly rural (intermediate) region". With the exception of Bratislava region was again entire Slovak republic considered to be rural, and population living in rural regions represented $88.8 \%$ of the total population of Slovakia. 
A different picture of Slovak "rurality" can be obtained at the level of LAU 1 units where the modified criterion for rural municipalities significantly influenced numbers of spatial units and share of the population in 3 categories of urban-rural typology. The category "predominantly urban region" was now represented by only 9 urban districts of two metropolitan towns Bratislava and Košice with $12.3 \%$ inhabitants of the Slovak Republic. Remaining population lived in 39 "significantly rural (intermediate) regions" and in 31 "predominantly rural regions". While in areas with the higher share of the rural population lived $34.7 \%$ inhabitants of Slovakia, in "intermediate regions" it was up to $53.0 \%$.

In the actual governmental document "Rural Development Programme in Slovakia for the 2014-2020 programming period" is rurality of Slovakia defined according to the new, revised urban-rural typology [4] that is based on the methodology focused on the elimination of the size differences between basic administrative units LAU 2 and NUTS III regions. In contrast to the original OECD methodology, the basic spatial unit used for the examination of the population density are population grid cells $1 \mathrm{~km}^{2}$. In the time of the preparation of the kind of urban-rural typology Slovakia didn't have such a cell grid for the disposal, hence the data at the level of LAU 2 supported by the CORINE land cover analysis were used. The purpose of the new methodology (see more [4]) is mainly the delimitation of urban areas and urban population. The grid cells that do not fit into criteria of "urbanity" are considered to be "rural" and the population inhabiting these areas is defined as "rural" population. The new, revised urban-rural typology is using the same spatial units - the administrative and statistical units NUTS III. However, the difference is in the threshold value which is used for delimiting urban and rural regions. The urban regions are defined as areas with maximum $20 \%$ of rural population. The initial threshold value $15 \%$ was changed to $20 \%$, while even the alternative $25 \%$ was considered. For the "predominantly rural regions" the threshold value remains the same: rural population living in rural territories represents more than $50 \%$ of total population. "Intermediate regions" are characterized by the share of rural population between $20 \%$ and $50 \%$ of total population.

According to the new urban-rural typology, Bratislava region which has area incompatible with other Slovak NUTS III regions remains the only predominantly urban region in Slovakia. The rest of the Slovak territory where around $88.6 \%$ of the total population lives is simply considered to be rural, yet not accurately. The difference with the previous governmental document is negligible. However, the important change is that the share of inhabitants of more numerous "predominantly rural regions" increased to $50.3 \%$ and on the other hand in "intermediate (significantly rural) regions" where compared to previous methodology 2 regions are missing the share of the inhabitants significantly decreased to $38.3 \%$. Within 27 EU states are these changes very essential and according to Buchta [3] it paradoxically means that by the applying new urban-rural typology [4] the rurality of Slovakia was significantly strengthened. 
Tab.2. Changes of the share of population in categories of urban-rural typology according to different governmental documents

\begin{tabular}{|c|c|c|c|c|}
\hline \multirow{2}{*}{$\begin{array}{l}\text { Governmental } \\
\text { documents for } \\
\text { years }\end{array}$} & \multirow{2}{*}{$\begin{array}{l}\text { Applied statistical } \\
\text { and administrative } \\
\text { units }\end{array}$} & \multicolumn{3}{|c|}{$\begin{array}{c}\text { Share of population in } 3 \text { categories of urban-rural typology in } \\
\%\end{array}$} \\
\hline & & $\begin{array}{l}\text { Predominantly } \\
\text { urban regions }\end{array}$ & $\begin{array}{l}\text { Intermediate } \\
\text { (significantly } \\
\text { rural) regions }\end{array}$ & $\begin{array}{l}\text { Predominantly } \\
\text { rural regions }\end{array}$ \\
\hline \multirow{2}{*}{$\begin{array}{l}2004-2006 \text { (rural } \\
\text { municipality = } \\
\text { below } 100 \\
\text { inhabitants } / \mathrm{km}^{2}\end{array}$} & NUTS III & $11.4(\mathrm{BA})$ & $\begin{array}{l}88.6(\mathrm{TT}, \mathrm{TN}, \mathrm{NR} \\
\mathrm{ZA}, \mathrm{BB}, \mathrm{PO}, \mathrm{KE})\end{array}$ & 0.0 \\
\hline & LAU 1 & 14.6 & 75.3 & 10.1 \\
\hline \multirow{2}{*}{$\begin{array}{l}2007-2013 \\
\text { (original OECD } \\
\text { classification) }\end{array}$} & NUTS III & $11.2(\mathrm{BA})$ & $\begin{array}{c}63.4(\mathrm{TT}, \mathrm{TN}, \mathrm{ZA} \\
\text { PO, KE) }\end{array}$ & 25.4 (NR, BB) \\
\hline & LAU 1 & 12.3 & 53.0 & 34.7 \\
\hline \multirow{2}{*}{$\begin{array}{l}2014-2020 \text { (new } \\
\text { urban-rural } \\
\text { typology) }\end{array}$} & NUTS III & $11.4(\mathrm{BA})$ & $\begin{array}{c}38.3(\mathrm{TN}, \mathrm{ZA}, \\
\mathrm{KE})\end{array}$ & $\begin{array}{c}50.3 \text { (TT, NR, BB, } \\
\text { PO) }\end{array}$ \\
\hline & LAU 1 & $?$ & $?$ & $?$ \\
\hline
\end{tabular}

Table 2 provides the overview of the presented changes in the share of population in 3 categories of urban-rural typology depending on the changed conditions of their definitions in governmental documents about rural development, and the selection of statistical and administrative units. (Note: The values of the share of population in 3 categories of urban-rural typology that would be obtained by applying LAU 1 units are not available for the actual programming period 2014-2020).

\section{CONCLUSION}

Delimitation of rural areas and/or the classification of administrative areas in terms of the level of rurality is usually based on an objective demarcation that complies with defined criteria, or on the subjective perception of rural territory (social construction of rurality) which differentiated image is the result of long-term formation of the rural landscape, way of life, and interpersonal relations in specific rural environment. While the first approach is used for the creation of strategic European policies [10], the second approach is becoming more inherent within the rural studies [5].

All methodological approaches mentioned in this study that lead to different delimitations of rural areas are based on the utilization of the number of inhabitants and on their spatial concentration exhibited by the population density. Hence, the methodological approaches are based on the quantitative data and so the resulting delimitation of rural-urban areas is controllable. After fitting selected criteria, the administrative territories at the various hierarchic level (LAU 2, LAU 1. NUTS III, ...) represent some kind of "boxes" to which could be assigned the adjective "rural". At the first sight the utilization of statistic indicators could lead to the idea that the objective picture of "rural", respectively "urban" character of areas can be obtained. Yet this is not entirely true. Unambiguously it was shown that the urban-rural typology is to a considerable extent a subjective matter because of changing criteria as well as defining threshold values according to subjective decisions and consequently regulating their utilization from "top-down" directives. The essential role is often played by pragmatic decision-making that affects the definition of criteria in order to obtain desired result. 
This leads to the conclusion that was pointed out by Hruška [5] according to whom no urban-rural typology should be the final answer to the question which area is "rural" and who can be considered as "rural inhabitant".

ACKNOWLEDGEMENT: This article was prepared as part of the Project No. 2/0035/15 „Development trajectories of localities and regions - product of sector and spatial policies, territorial capital and decisions", funded by the Slovak VEGA Grant Agency. The author thanks to the Slovak VEGA Grant Agency for its financial support. Special thanks go to Ms.Veronika Korčeková for her help with translating this article into English.

\section{REFERENCES}

[1] Bezák, A. Development of urban and rural population in Slovakia between 1970 and 1995. Geographica Slovenica, Slovenia, 1999, vol. 31, pp.170-177.

[2] Bezák, A. O regionálnych trhoch práce, nových krajoch a tokoch nezamestnaných. Geografický časopis, Slovakia, 2001, vol. 53, pp.295-305.

[3] Buchta, S. Vývojové trendy vidieckych a mestských oblastí Slovenska. Ekonomika pol'nohospodárstva, Slovakia, 2012, vol. 12, pp.48-67.

[4] European Commission. Eurostat Regional Yearbook 2010. Publications Office of the European Union, Luxembourg, 2010, 264 pp.

[5] Hruška, V. Proměny přistupů ke konceptualizaci venkovského prostoru v rurálních studiích. Sociologický časopis / Czech Sociological Review, Czech Republic, 2014, vol. 50, pp.581601.

[6] Hurbánek, P. Recent developments in definitions of rurality/urbanity. Focus on spatial aspect and land cover composition and configuration, EUROPA XXI, Poland, 2008, no. 17, pp 9-27.

[7] OECD. Creating Rural Indicators for Shaping Territorial Policy Organisation for Economic Co-operation and Development. OECD Publications and Information Centre, Paris, 1994, $93 \mathrm{pp}$.

[8] Perlín, R. Theoretical approaches of methods to delimitate rural and urban areas, European Countryside, Czech Republic, 2010, vol. 2, pp.182-200.

[9] Podolák, P. Demographic changes of rural population in Slovakia. In: Floriańczyk, Z., Czapiewski, K. (eds.). Rural development capacity in Carpathian Europe. Rural areas and developmet, vol.3, European Rural Development Network, Warsaw, Poland, pp. 49-62, 2005

[10] van Eupen, M. \& Metzger, M.J., \& Pérez-Soba, M. \& Verburg, P.H. \& van Doorn, A. \& Bunce, R.G.H. A rural typology for strategic European policies, Land Use Policy, 2012, vol. 29 , pp. 473-482. 